\title{
PREPARING AND CONDUCTING OF MUSICAL REFORM IN RUSSIA OF 1650-1670-ies*
}

\author{
N. P. Parfentiev, South Ural State University, Chelyabinsk, Russian Federation, \\ parfentevnp@susu.ru
}

In this paper the author examines the practical activities of the authorities in organizing of special commissions, in order to eliminate negative phenomena in church chanting and carry out its reform. The commissions consisted of leading masters of church singing art. The researcher, on the basis of documentary and narrative sources, was able to clarify the dates of work and the names of the members of the commissions, to reveal the general results of their activities.

Keywords: Old Russian church chanting art, razdelnorechie, correction of singing books, commission of didascaloi (musicians-theoreticians).

The transition period art appeared a joining link between the Medieval art and the New Time art. During the transition period the Russian professional musical art also went through drastic stylistic changes. The Old Russian chant was gradually replaced by colorful, virtuosic and harmonically rich singing - "partesnoe". Russian musicians took it differently. Most of them, supported by higher authorities and with the help of Ukrainian chanters, were mastering the new art. Others tried to refresh the Ancient Russian chant reforming it in the way they felt necessary. By the 1650-s in the Russian church singing a wide range of negative tendencies was dominated which was formed during previous centuries (in particular so-named "razdelnorechie"). The acute need for the reformations was felt at least a century before the time when the authorities finally got down to long-anticipated transformations.

There is only one discovered source of information about the work of the First commission and that is the introduction to the treatise of the Second Commission "Notification... to those wishing to study chant singing" («Извещение... требующим учитися пения»), written by "Alexander Mezenets and others". The insufficient data presented there specify the precise date of the Tsar's order to gather fourteen didascaloi (teachers of chanting) in Moscow to have them work in this agency. However, researches of different periods mention different dates when the commission started working [2, p. 117].

The first interpretation of the introduction to "Notification" was given by Metropolitan Evgeny (Bolkhovitinov) who said that fourteen "teachers" had been selected according to the Tsar's "decree of 1652 " [16, p. 156]. Quoting the text under discussion, V. M. Undolsky published the $7160(\cdot \overline{\cdot 3 P 3} \cdot)$ year stated in the text as 1652 [77, p. 12-13). I. P. Sakharov, speaking about the work of the commission, transformed 7160 into 1651 , but added that the correction of chant books was launched in 1652 [73, v.1, p. 28; v. 2, p. 11). D. V. Razumovsky mentioned in all his works that the

\footnotetext{
* Статья выполнена при поддержке Правительства РФ (Постановление № 211 от 16.03.2013 г.), соглашение № 02.A03.21.0011.

1 "Razdelnorechie" ("homonia") is a specific manner of verbal texts singing with insertion into the words of nonexistent in the usual speech vowels between consonants. That is why it is called "separate speech", which was predominantly the result of Ancient Russian semi-vowels $\boldsymbol{b}$ and $\boldsymbol{b}$ voicing that had neuma above them, and also the result of replacing them with $\boldsymbol{o}$ and $\boldsymbol{e}$ in writing.
}

First commission began working in 1652 . He proved it with the lists of "Notification" and believed that the most sufficient list was the one stored in Undolsky's library $[50$, fol. $1 ; 25$, p. 81,$138 ; 26$, p. 50$)$. Another outstanding scholar who studied the Russian medieval music, S.V. Smolensky, reported in 1887 about finding a list of "Notification" in the manuscript of a Kazan tradesman called L. Yelkin, and also mentioned the discovered data about two commissions, the first one of which gathered in 1652 [75, p. 9, 16]. But, publishing the entire "Notification" in 1888 on the base of the list of "Yelkin's manuscript", he put the year 7163 (1655) $[3$, p. 1].

Being a very elaborate researcher, V. M. Metallov, who knew "Notification" from different manuscripts, refers to the first date when speaking about the start of the activities by the commission assembled by 14 didascaloi in his "Essay on the history of the Orthodox church chant in Russia". This caused a wave of criticism from A. A. Ignatyev, who blamed Metallov for blind following D. V. Razumovsky. To prove that the First commission gathered in 1655, Ignatyev presents these facts: the correction of chant books was under way during the reign of Nikon (he was the patriarch since July 1652), for the former patriarch Iosif was against the liquidation of the so called "razdelnorechie", which is proved by Nikon's biographer Ivan Shusherin [74, p. 21]; "pestilent wave" (epidemic of plague), which is stated in "Notification" as one of the reasons for the stoppage of the commission's work in Moscow in the late 1655 (this provision is not grounded); and finally, the main proof, "written" evidence of "Notification" as published by S. V. Smolensky [17, p. 32-35].

A. A. Ignatyev's work was commented by V. M. Metallov. His highly scientific article issued in one of the Moscow Ecclesiastical Academy periodicals settled the problem of the time of the First Commission's first gathering very convincingly and stated that it happened in 1652 [20, p. 423-50]. However, this work seems to have been known to a very small range of people and then it was forgotten. In any case, until now, the majority of researchers, following S. V. Smolensky and A. A. Ignatyev, believe that the activities of the First commission began in 1655 . That is why there is a necessity to touch upon V. M. Metallov's article to study his grounds briefly and to provide supplementing and clarifying. 


\section{Искусствоведение}

Analyzing the proofs presented by A. A. Ignatyev, the researcher notices that "Notification" does not specify who was the patriarch when Tsar Alexei Mikhaylovich ordered to gather didascaloi, but it states clearly that the gathering was conducted "with the blessing" of Iosif. As the latter insisted, the Council of 1649 held that "the service should run as before and nothing is to be changed"; but later, after conferring with the patriarch from Tsargrad (the then name of Constantinople) at the Council of 1651 Iosif changed his mind and supported the proposal on the necessity of chant correction. Metallov assumes that this order could hardly be issued directly from the Tsar during the election of the new patriarch, i.e. during the period from Iosif's death to the appointment of Nikon, from April 15 to July 25, 1652. Even if it had been issued then it would have had to be confirmed by the council [20, p. 431-434] $]^{1}$. After the start, apparently, in the summer of 1652, the First Commission was soon forced to abort its work. In the spring of 1654, the war against Poland broke out [20, p. 436]. Later, according to S.M. Solovyev and I. E. Zabelin, in the July-December period, the first and deadliest outbreak of plague began in Moscow. Then, V. M. Metallov wrongfully tries to present the period from July to December 1654 as that from July 1653 to December 1654 according to the September chronology $[20, \text { p. } 438]^{2}$ (a year starts with September). That is why he suggested that the commission worked for about a year or a year and a half. Finally, having outlined the drawbacks of "Notification" version published by Smolensky (in particular, the reproduction of the text based on Yelkin's manuscript without considering differences in other manuscripts), V. M. Metallov refers to written sources, manuscripts of that time.

First of all, these are manuscripts of "Notification" known to S. V. Smolensky as well. One of them missed the beginning of the preface and thus the date of the gathering of the First Commission. Another manuscript envisages the year 7160 [50, fol. 1]. In Russia in those times years the chronology was counted not from Jesus Christ's Birthday, but from the Year of the World's Creation. The same date is stated in the following manuscript introduced into the research by S.V. Smolensky himself [72, fol. 64]. Then, V. M. Metallov passes over to the manuscripts known to him. The first one reports that it was in the year $7160(\overline{\mathbf{3 P}} \cdot)$, while the second one names the year of the "7160-го" [12, fol. 408; 13, fol. 1]. Thus, the researcher supposes that S. V. Smolensky did not preserve the element "го" in "7160-го" when preparing the published version. This "го" must have also been in Yelkin's manuscript that was the basis for

${ }^{1}$ The decree of the tsar was a consequence of the Council of 1651 and could appear precisely during the period of the change of the Patriarchs, or at the very beginning of the patriarchate of Nikon. "Notification" is written after the Council of 1666-1667. Perhaps, its authors did not begin to mention Nikon, condemned by this cathedral. But, undoubtedly, the commission was assembled after the death of Patriarch Josif.

${ }^{2}$ In this case, it turns out that the epidemic in Moscow lasted a year and a half - from July 161 (1653) to December 163 (1654). Documents show that it began in July and ceased in December of the same year in 1654 [15, p. 442-522]. this work. This could be the circumstance that gave rise to the date $7163(\overline{\mathbf{3 P} \not 2 \Gamma} \cdot)$ or 1655 A. D. [20, p. 442-445].

All the four manuscripts of "Notification" enumerated by V. M. Metallov have one and the same year of the First Commission's gathering, 7160 (1652). This date is found in other manuscripts. In some manuscripts it is said "the year of 7160-го". Only in one of them, belonging to the times of the last quarter of the $17^{\text {th }}$ century, we can find letters ". $\mathbf{3 P \not ू \Gamma . " ~ [ 4 9 , ~ f o l . ~ 4 1 2 ] . ~ I t ~ i s ~ i m p o r t a n t ~}$ to note that the scriber of this manuscript acted like a vey illiterate copyist as he made a lot of mistakes and omitted many words and letters. He must have made a mistake writing " $\overline{\mathbf{3 P} \not 2 \Gamma}$.". Besides, ten other manuscripts containing the introduction to "Notification" are very trustworthy. Thus, it seems to prove that the work of the First Commission began in 1652 .

So, in the summer of 1652, Tsar Alexei Mikhaylovich deigned to found an agency of church plain chant correction. As it was already said, the Tsar himself was very fond of ancient chant art. Being an expert in all nuances of church singing since his youth, the Tsar, apparently, had long ignored the wrongs in this system. But when the question of its reforming grew extremely urgent, Alexei Mikhaylovich decided to initiate these actions. First of all, by the Tsar's order, fourteen chant masters were gathered in Moscow. "Notification" has little information about these people. It is known that the First Commission was composed of the representatives from various levels of church hierarchy "from heads of holy places to different chosen God's people" [2, p. 117].

The members of the Second Commission received their payments through the Typography Department while the commission worked at the Moscow Printing House (details are given further). There is no information about the First Commission. The 1650-s Records of the Typography Department do not have any data of that kind. We do not know so far the names or ranks of those fourteen didascaloi ${ }^{3}$. This commission worked until the summer of 1654 (when, in the conditions of war and epidemic, it had to shut down), i. e. for about two years. Considering those ambitious objectives set before the chant masters, let us try to find out what they managed to do within that period of time.

First of all, the didascaloi, apparently, collected a large amount of ancient manuscripts on chant including many of those which were in "staroistinnorechie". At that time, it was arranged to correct chant and other books according to ancient books. "Notification" says that the Second Commission possessed ancient parchment "hand-written Hirmologions" and books of "other church chants", which were "written four hundred years before and were withering" [2, p. 121], i. e. were written in the $13-14^{\text {th }}$ centuries. Judging by the short period of work produced by the Second Commission and small number of its members, we may assume that these manuscripts were collected by the members of the First Commission. The 1652 books of charges at the Typography Department have a lot of records concerning the purchasing of several

${ }^{3}$ V. V. Protopopov suggested that the First Commission was not assembled at all [24, p. 34-35]. 
hand-written books for as samples for correction [35; 36 and others].

To settle the issue of stylistic similarity of musical texts it was required to enhance and unify the notation system. In line with it, it is important to consider V. M. Metallov's remark that cinnabar red ink signs "zarembas" which denoted more clearly the pitch of a sound were probably organized and corrected by the First Commission [20, p. 439]. Written in the 1670-s, "Tale of Zarembas" ("Сказание о зарембах") says that these 'signs were created during Tsar Michail Fedorovich's ruling' by Luka Ivanov (Moscow), Feodor Kopyl (Veliky Ustiug), Semeon Baskakov (Nizhny Novgorod), hegumen-abbot Pamvo (Vologda), Grigory Zepalov and Kirill Gomulin. The correction of signs continued in the times of Alexei Mikhaylovich by Lev Zub, Ivan Shaidur and Tikhon Korela. The author of the "Tale of Zarembas" writes that he personally knew the masters ("and I heard them and saw their versions; and after speaking with them, wrote what I had learned") [12, fol. 376-378].

Numerous manuscripts of the first half of the $17^{\text {th }}$ century contain the znamenny neumatic signs. Some of them were preserved in the following years ( $p, \sigma, m$ and others), but many of them disappeared in the later works $(\partial, o, c 6$ and others) $[30 ; 31 ; 47 ; 55 ; 58$; $59 ; 60 ; 70 ; 71]^{1}$. Approximately since the $1650-\mathrm{s}$, cinnabar signs became widely applied and were known in literature as the "Shaidur system". The basis for calling them after the name of Shaidur is another work, "Tale of marks used in chant". Its author reports that "God revealed a key to marks" to a Novgorod citizen Ivan, Akim's son, who had an awkward nickname, Shaidur [52, fol. 5-6].

M. V. Brazhnikov already questioned the theory that this very Shaidur was the only author of the signs (those discovered in "Tale of Zarembas" and in "Notification"). As well as the church znamenny chant system, the system of signs also required systematization. This researcher associates this process with the work of the Second Commission [11, p. 296]. We believe that this was done earlier, by the First Commission. The Second Commission did not work for a long time. Working in the field of theory, the members of the Second Commission ignored marks and used them (already systemized and known to singers) only to explain the system of the signs they were introducing: "The signs that have been used before are mentioned here only for the purpose of brief explanation"; and then this purpose is outlined [2, p. 118]. It is highly possible that separated masters-theoreticians, with whom the author of "Tales of Zarembas" used to talk a lot, gathered together to work out a standard theory of signs and notation unification. They studied signs of the former theoreticians (it is very possible that these were the ones who reported the author about the other masters), but the biggest recognition was earned by Novgorod-born I. A. Shaidur and his system which was taken for the basic one. The sources do not verify that these didascaloi arrived to form the First Commission, but the time of their activities coincides with that of the First Commission. These masters did not

${ }^{1}$ Let us point out the unique "Tales of the Signs" (the end of the seventeenth century), which speaks of the significance of these signs [48, fol. 173]. have enough time to establish a generalizing theoretical manual (they only systemized the signs) and, due to the forced ending of the work, parted their ways. That is how the system of signs in a short while became known across the country and was introduced to the collections of Russian plain chants.

It is obvious that before the start of the First commission's activity, the problem of centralized chant book production was reckoned as highly urgent. In 1652, at the Moscow Publishing House, Feodor, Ivan's Son, Popov was entrusted with the "launching of the znamenny chant book typing" [22, p. 41]. But since the didascaloi chose the way of introducing cinnabar signs, this hindered the fast realization of the idea, and then hampered the whole music reformation for many years.

The First Commission executed preliminary works and only started the reformation of the chant art. After the first steps towards znamenny chant correction were stopped in the summer of 1654, in 1654/55 and 1655/56 "and the years to follow, the process that was started in Moscow, the ruling city, continued in all towns, villages and monasteries with each master going through the correction of his singing" [2, p. 118]. Many of the preserved manuscripts and documents prove these words from "Notification". The editing of chant books, for example, was under way in Savvo-Storozhevsky Monastery $[27 ; 28 ; 29$ and others]. In June 1662, diak of the first stanitsa Tsar's choir, Ivan Nikoforov was granted with expensive cloth for "writing narechnoe neumatic singing for the Fest of St. Theodore Stratelates" [32, fol. 103]. Alexander Mezenets started correcting books after settling down in the house of "protector of corrected chant", of the duke U. S. Urusov, in June 1666 [14, fol. 1]. However, masters, who were scattered all over the nation, "failed to come to agreement". Because of the "great differences in views" in Russia, "even two could not sing together in one church, not to mention three or more" [2, p. 118]. To overcome the differences and correct the chant system, it was necessary again to gather the best masters and continue the work started by the First Commission.

There is no precise information in sources about the time of the Second Commission's establishment. I. P. Sakharov believed that it happened in 1668 [73, v. 1, p. 30]. D. V. Razumovsky first thought that it was in 1656 [25, p. 90], but then began considering the commission's work as the consequence of the Moscow Council in 1666-1667 [26, p. 79]. All the following researchers also associated the gathering of the Second Commission with that Council, but referred it to 1666,1667 or 1668 [11, p. 335; 19, p. 1; 75, p. 14, 16; and others].

In the introduction to "Notification", it is said that Tsar Alexei Mikhaylovich, after conferring with patriarch Ioasaf, "ordered to his Right Reverend Pavel, metropolitan Sarsky and Podonsky, to gather masters who knew chanting well". Overall, they managed to find six masters $[2$, p. 118]. Since it is known that in the 1660-s and 1670-s Pavel headed the Moscow Publishing House, it was reasonable to seek information about the Commission in the documents issued by the Typography Department that regulated the work of that Publishing House. 


\section{Искусствоведение}

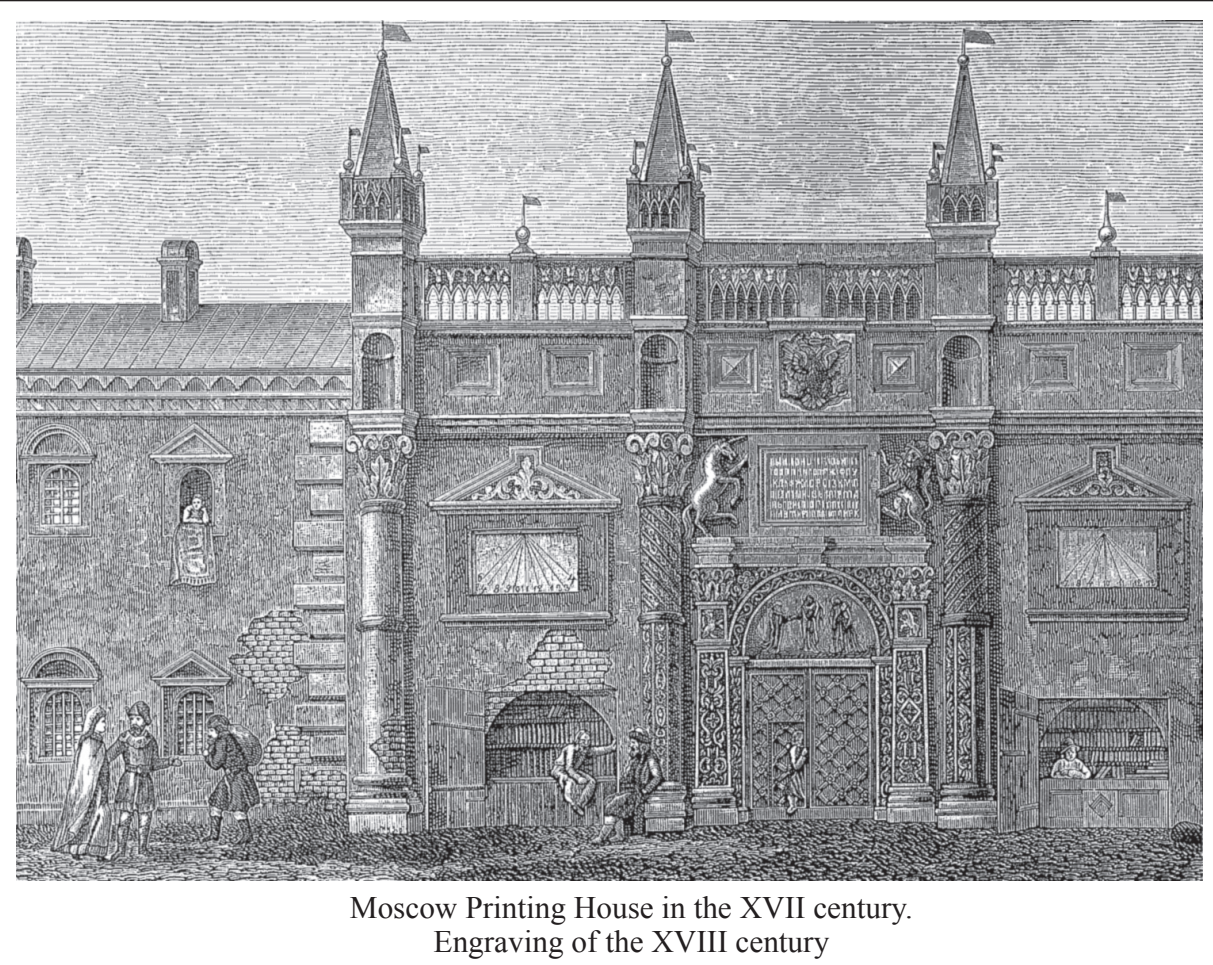

The first review of these documents was prepared by I. Mansvetov with even some data about several members of the Second Commission [18]. The research work with these resources started by Mansvetov was continued by D. V. Razumovsky. He published the names of all six masters and copies of their autographs. However, the researcher gave wrong references to the sources having written that autographs are copied from the books of charges number 171 and 172 (1663 and 1664) [26, p. 50-51]. V. M. Metallov, proceeding from that, assumed that "the First Commission of 14 people $<\ldots>$ later was not dissolved completely, but some of its members then stayed at the Publishing House and continued what they had been doing"; which means that the Second Commission "partially or fully was composed of the former members of the First Commission of 1652" [20, p. 448-449].

We scanned in RGADA the preserved books of charges and salaries at the Typography Department for the period from 1640 to 1680 [33-40; 43 etc. ${ }^{1}$. Judging by the published documents, D.V. Razumovsky was familiar with the affairs of files number [40] (1663-1664) and number [43] (1667-1674). However, he admitted that the documents he had studied embraced only the period framed by 1663 and 1664 . The numbers of the pages with the names of the commission's members are also given incorrectly. For example, only two out of six pages singled out by the author from file number [40] do have the required autographs and records.

V. M. Metallov's point of view based on the assumption that the Second Commission involved the members of the commission active in 1652-1654 should be found inconsistent. All the autographs (we can also find them in books for 1661 and 1662) belong to the only one member of the Second Commission, Alexander Pech-

\footnotetext{
1 These sources supplement the books of decrees on the work of the Printing house: [41 (1667); 42 (1664-1724); 44 (1667-1676); 45 (1668-1689)].
}

ersky. Earlier, this Elder from the Chudov Monastery was a regular editor at the Moscow Publishing House (since March 1661) [37, fol. 498; 38, fol. 2; 39, fol. 6] $]^{2}$. But there are no grounds to assume that he "accommodated himself" after working at the First Commission.

The list of the Moscow Publishing House editors from the books of salaries for 1657, presented by I. Mansvetov, beside Alexander Pechersky, has the name of "Elder Alexander" $[18$, p. 27]. Some researchers tend to think that this is another name of one more well-known (mentioned in "Notification" too) member of the Second Commission, Alexander Mezenets ${ }^{3}$. Indeed, a book expert, Elder Alexander arrived at the Publishing House and started his work there since September 1657. He named himself "monk Alexander" when putting his signature to prove the reception of the Tsar's payments [36, fol. 333,$393 ; 37$, fol. 57]. The comparison of the handwritings shows that the "monk's" handwriting belonged not to Mezenets, but to monk Alexander Shestakov [40, fol. 4].

Therefore, the supposition that the members of the commission working in 1652 through 1654 later worked in the Second Commission is not confirmed by the resources yet.

The most sufficient data about the members of the Second Commission are given in the book of charges for 1667-1674 issued by the Typography Department. This book has a record reading according to the Great Tsar's order of October 177 (1669), The Typography Department for the work with znamenny chant books should pay two altyns (6 kopecks) daily apiece to Yaroslavl's diakon Kondrat Larionov, Reverend Patriarch chanter diak Fedor Konstantinov, Grigory Nos from Vologda and Faddey Nikitin from Usol'e - from the

\footnotetext{
${ }^{2}$ Only the name "Alexander" is indicated here. According to the handwriting one can identify Alexander Pechersky $[40$, fol. 3,94$]$.

${ }^{3}$ N. D. Uspensky noted that Mezenets was the editor of the Moscow Printing House from 1657 year [78, p. 493]
} 


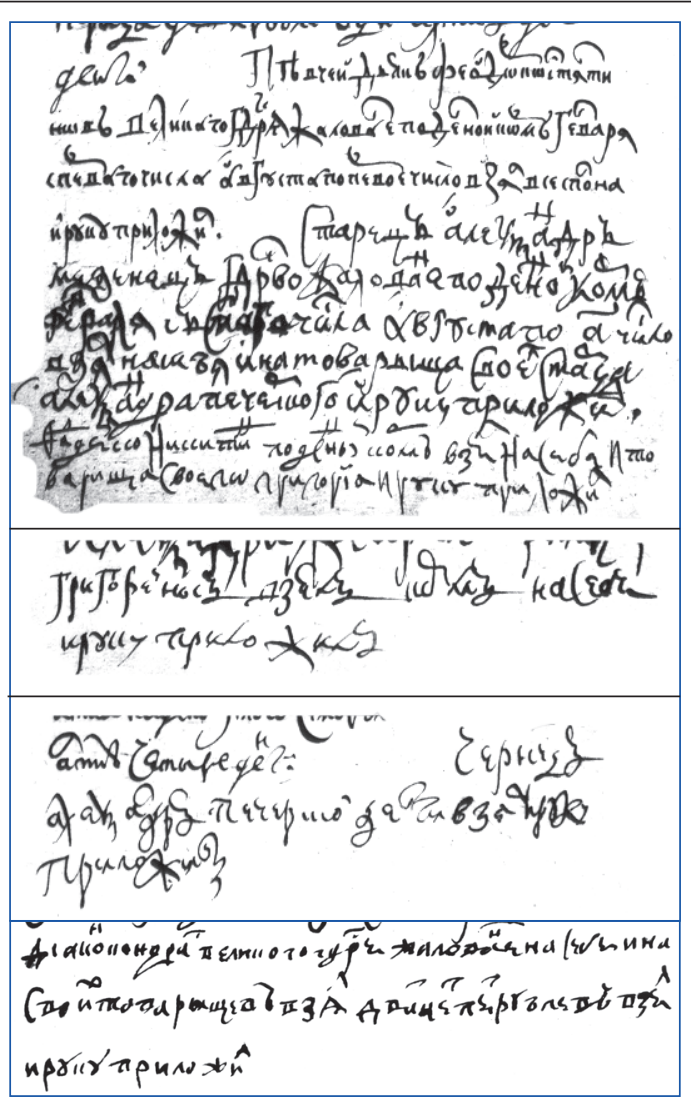

The Second Commission Members' signatures in receiving a salary: Feodor Konstantinov, Alexander Mezenets, Faddey Subotin, Grigory Nos, Alexander Pechersky, Kondrat Larionov

[43, fol. 153, 172 об., 186 об., 99]

first of January 1669, and to Elder Alexander Pechersky from the Chudov Monastery and to Elder Alexander Mezenets from the Savin Monastery - from the eighth of February until the first August of the following year. Then there are calculations of sums to be added after withholding the advance payments issued in April and May 1669, and finally, the signatures of the didascaloieditors proving the reception of these sums [43, fol. 152]. This determined the regular financing of the commission's work.

According to this record, the members of the commission did not start their work there at the same time. Kondrat Larionov, Feodor Konstantinov, Grigory Nos and Faddey Nikitin began on January 1, while the Elders Alexander Pechersky and Alexander Mezenets - on February 8,1669 . There are reasons to believe that during 1668 , there was held a correspondence with the then widely-known music centers and masters went through strict selection to demonstrate "good knowledge of znamenny chant" and were gathered in Moscow. The activity of the Second Commission was launched in January 1669. After three months of work of the regular masters and two months of work of the elders, they all were given the first payments. In October 1669, the commission was paid almost fully for the whole period of work in the previous year (from September 1669). Later, payments "two altyns for one day" were given to the editors after four or five months of work [43, fol. 163, 172]. As a rule, all expenses on the commission were registered after paying the money to the full-time workers of the Publishing House or in "other charges". This means that from the very start the commission was seen as a short-time institution.

The six chant masters stayed as members of the Second Commission for different periods of time. They started and finished their work at different time. Apparently, the length of their staying depended on the type of work each of them was supposed to do there. Moscow gathered masters who knew all the nuances of the Old Russian chant art: "these were masters who knew the Moscow, Krestianinov, Usolsky and other versions" [2, p. 118]. Common members of the commission presented various chant centers and, evidently, were supposed to edit and unify melodic materials. Elder Alexander Mezenets stood forward as the leading chant theoreti$\operatorname{cian}^{1}$. A former full-time editor ${ }^{2}$, Alexander Pechersky was invited to the commission rather as a literary editor of the chant books. After completing their tasks, the members of the commission left.

The first one to leave the commission was Yaroslavlborn Kondrat Larionov (after May 1669 he was not paid for the work at the commission). The labor of the Patriarch's diak Fedor Konstantinov and Usol'e-born Faddey Nikitin was paid until December 1669. Finally, on April 21,1670 , the rest of the editors, Alexander Pechersky, Alexander Mezenets and Grigory Nos, received their last payment for the work done from December 1, 1669 to May 1, 1670. Thus, the Second Commission of chant book correction worked approximately from January 1669 to April 1670 and finished its activities after a year and a half of its work. The names of the elders are separately mentioned in other documents of the following years.

"Notification" points out that the first result of the six-master commission was the correction of the chant Hirmologion: "And they first corrected a book of znamenny chant hirmuses" [2, p. 118]. The correctors fully edited texts and melodies of hirmuses. Since then the structure of the Hirmologion's manuscripts was not the same. For example, during the whole $16^{\text {th }}$ century and the first half of the $17^{\text {th }}$ century, the selection of hirmuses was extremely stable. The manuscripts usually included about 690 hirmuses (without rosniks - a special genre). Starting with the last third of the $17^{\text {th }}$ century, the succession of hirmuses changed greatly.

The correction of the chant Hirmologion was conducted in several ways: the texts of hirmuses were verified according to the oldest hand-written and "newly corrected" typed books. Some of the hirmuses were completely eliminated, but a large amount of new ones was introduced from the Kanons that had not been used in the service-chant practice. After all corrections and supplementations, the general number of hirmuses in the collection grew one and half time bigger (about 1020) $[51 ; 53 ; 57 ; 61 ; 65 ; 68$ etc.]. Nevertheless, alongside the new version of the Hirmologion manuscript, the making of copies with the selection of hirmuses similar to

${ }^{1}$ In «Notification" his leading role in the compilation of this tractate is indicated: "Written by Alexander Mezenets and others" (“Трудился Александер Мезенец и прочии”) [2, p. 208-209].

${ }^{2}$ Among the editors of 1667-1668 the name of Pechersky is not mentioned [43; 44]. Probably by this time he left the service at the Printing House. 


\section{Искусствоведение}

the manuscripts of the earlier periods was continued. The main difference was in the corrected verbal texts [7; 8; 69 etc.]. Consequently, the Hirmologion final version was presented in two types of manuscripts. The first one may be called "complete"; the second one the shortened variant of the first one, i.e. incomplete. The Hirmologion was supposed to become a specific sample for the correction of other chant books. Besides, according to Old Believers' traditions, the Hirmologion was the main book to rely on while mastering the art of znamenny chant [21, p. 85-89; 76, p. 40-61]. The commission's musical-theoretical work "Notification" was written on the basis of and as an appendix to the Hirmologion. As mentioned above, the original of the corrected Hirmologion, apparently, was kept in the Tsar's library: its inventory for 1682 has records about "Plain hirmuses written by the masters at metropolite Pavel Krutitsky" [23, p. 131].

It was possible to preserve the further unified edition of melodies and texts of chants only through the centralized publishing of corrected chant books. Technically, the typing of neumatic notation books was not an easy process, which was aggravated by the introduction of cinnabar signs. After taking up the preparation of musical texts for typing, the masters inevitably faced the question of further enhancement of znamenny neumatic notation. It was decided to apply the signs of limited purpose which were invented long before the Second Commission. Basing on the system of cinnabar signs, the didascaloi, in fact, created a new well-organized system of signs. Their commission declared: "Now the cinnabar signs, the indication characters of the old znamenny chant can not be in typed pressing, but they will be replaced by other sings" [2, p. 119]. As the sings were written as constitutive parts of znamenny chant neuma, they had the function of cinnabar signs (indicating pitch correlations between the neuma of notations), and were most appropriate for the typographic reproduction of plain chant texts. Shortly after the work of the Second Commission, the Publishing House got down to the execution of this important task.

Following D. V. Razumovsky's assumptions, the research literature widely presented an opinion that only in 1678 the Publishing House prepared a "full set of znamenny chant neuma" for the typing of chant books [19, p. 11]. However, the sources inform that this work was produced within one year after the Second Commission. Thus, in March 1671, Pavel ordered to pay 10 rubles to type-setter Ivan Varfolomeev for the development of znamenny neuma and setting up samples based on them. Finally, on May 16, 1671 Tsar Alexei Mikhaylovich instructed to print 2400 books of hirmuses with new versions of chanting [43, fol. 221, 238; 44, fol. 45, 46; 45, fol. 6]. Nevertheless, for some unknown reasons, this was not executed. In any case, there has not been discovered any printed znamenny chant Hirmologions or other chant books. As for the made punches, matrixes, set of neuma, they were stored for a long time at the Moscow Publishing House. P. A. Bessonov found records about them in the Inventory of the House for 1681, and later, in the documents of the $18^{\text {th }}$ century $[4$, p. $28-30]$.

Alongside the Hirmologion other chant books were brought in correspondence with non-chant church books. In some of them, not only texts and melodies were corrected, but the content of compositions was also changed. In the Octoechos, all chants of small vespers were replaced, which is the best sign of the new version of the manuscript ${ }^{1}$. In the Feasts, sticheras were mostly changed in small vespers for the mobile feasts sticheras without fixed dates ${ }^{2}$. In other chant books, texts were mostly only corrected. Without waiting for the start of regular and massive printing, the government established a group of scribers who started working immediately ${ }^{3}$. Simultaneously, the capital and eparchial centers sent away letters to cities and monasteries to instruct the churches "to sing and speak edinoglasie and in narechie, without resistance, according to the newly corrected hand-written and printed books" [1, p. 235-236, 401-402 etc.]. Narechnoe books (establishing one universal church language) were widely spread as early as in the 1670 -s, which is proved by the records left in them by the scribers and owners.

So, the Second Commission successfully accomplished the reformation of the Ancient Russian znamenny chant. However, the masters-reformers were late. The Russian musicians of the second half of the $17^{\text {th }}$ century were focused on the so called Partesny (Polyphony) chant with easier theories and notation. The editors of ancient chant failed to do everything they had planned, but these six people, some of the best masters of the Russian dying art, are not the ones to blame.

\section{References}

1. Acty, sobrannye v bibliotekakh $\mathrm{i}$ arkhivakh Rossiyskoy imperii Arkheograficheskoy ekspeditsiey [Acts collected in libraries and archives of the Russian Empire by Archaeographic expedition.], v. 4. St. Petersburg, 1836.

2. Alexander Mezenetz i prochii. Izveschenie... zhelayuschim uchit'sya peniyu (1670) [Alexander Mezenets and others. Notification... to those who wish to learn singing (1670)]. Publ. N. P. Parfentiev, Z. M. Guseynova. Chelyabinsk, 1996.

3. Azbuka znamennogo peniya (Izveschenie o soglasneyshikh pometakh) startsa Alexandra Mezentsa (1668-go goda).

\footnotetext{
${ }^{1}$ For example, in the first mode section previously were: Theotokion "Raduisya ot nas" ("Радуйся от нас"), sticherons "Netlennorozhdich Boga" ("Нетленнорождиш Бога"), "Ognya bozhestvennogo" ("Огня божественного"), "Uvy mne chto budet" ("Увы мне что будет") and Theotokion "Se k tebe prikhozhu" ("Се к тебе прихожу"). Now, after the correction, chants "Devstvennoe torzhestvo" (“Девственное торжество"), "Preblagoslovenna esi” (“Преблагословенна еси”), "Oderzhimii skorbmi” (“Одержимии скорбми”), "Obnovisya mir" (“Обновися мир") and "Oblak tya sveta" (“Облак тя света") were included respectively $[5 ; 6 ; 46 ; 53$; 56; 64; 66 etc.].

${ }^{2}$ For example, in the Ascension of the Lord the choristers previously sung the sticherons: "Ty chelovekom suschestvo" (“Ты человеком существо"), "Apostolom Khristovym" (“Апостолом Христовым") and "Vozneseniem tvoim" ("Вознесением твоим"), ended by chant-slavnik "Priidite vernykh sobori" ("Приидите верных собори"). Now, after the correction, chants: "Gospod' voznesesya" ("Господь вознесеся"), "Gospodi tvoemu vozneseniyu" ("Господи твоему вознесению"), "Na gorakh svyatykh" ("На горах святых"), "Gospodi smotreniya" ("Господи смотрения") were included respectively $[9 ; 10 ; 46 ; 54 ; 62 ; 63 ; 67 ; 68$ etc.].

${ }^{3}$ In one of the records for 1671 it is said that "the scribe of narechnoe singing" Semen Isidorov received a cinnabar [43, fol. 272].
} 
Izd. S. V. Smolensky [Textbook of plain chant (Notification of agreed marks) of the Elder Alexander Mezenets (1668). Published by S. V. Smolensky]. Kazan', 1888.

4. Bessonov, P. A. Sud'ba notnikh pevcheskich knig [The fate of chant books]. Pravoslavnoe obozrenie [Orthodox outlook]. Moscow, 1864. № 5.

5. BRAN. Arkhang. № 30.

6. BRAN. Arkhang. № 35.

7. BRAN. Arkhang. № 40.

8. BRAN. Arkhang. № 41.

9. BRAN. Arkhang. № 43.

10. BRAN. Arkhang. № 44.

11. Brazhnikov, M. V. Drevnerusskaya teoriya muzyki

[Old Russian theory of music]. Leningrad, 1972.

12. GIM. Sinod. pev. № 219.

13. GIM. Sinod. pev. № 727.

14. GIM. Sinod. pev. № 728.

15. Dopolnenija k actam istoricheskim, sobrannii i izdannii Arkheograficheskoy Komissiey [Additions to historical acts collected and published by the Archaeographical commission]. St. Petersburg, 1848, v. 3.

16. Evgeny, mitrop. O Russkoy tserkovnoy muzyke [Of Russian church music]. Otechestvennye zapiski [Home notes]. St. Petersburg, 1821. p. 156.

17. Ignatiev, A. A. Tserkovno-pravitelstvennye komissiyi po ispravleniyu bogosluzhebnogo peniya russkoy tserkvi vo vtoroy polovine XVII v. [Church-state commissions of correction of the Russian church chant in the second half of the $17^{\text {th }}$ century]. Kazan', 1910, pp.32-35.

18. Mansvetov, I. D. Kak u nas pravilis' tserkovnye knigi [How the church books had been revised]. Moscow, 1883.

19. Metallov, V. M. Azbuka kriukovogo peniya [Book of plain chant (kryuki) notes]. Moscow, 1899.

20. Metallov, V. M. K voprosu o komissiyakh po ispravleniyu bogosluzhebnykh pevcheskikh knig russkoy tserkvi v XVII v. [About the commissions for the correction of the Russian church chant books in the $17^{\text {th }}$ century]. Bogoslovskiy vestnik. [Theological herald]. Sergiev-Posad, 1912, v. 2, № 6. pp. 423-450.

21. Mironova, N. V., Parfentiev, N. P. O metodike obucheniya drevnerusskomu pevcheskomu iskusstvu [About the methods of teaching Old Russian chant art]. Iz istorii dukhovnoy culture dorevolutsionnogo Urala [From the history of the pre-revolution Ural's intellectual culture]. Sverdlovsk, 1979. pp. 85-89.

22. Preobrazhensky, A. V. Kultovaya muzyka v Rossii [Cult music in Russia]. Leningrad, 1924.

23. Protopopov, V. V. Notnaya biblioteka Tsarya Fedora Alekseevicha [Music library of Tsar Feodor Alekseevich]. Pamyatniki cultury. Novije otkrytija, 1976 [Cultural heritage. New discoveries. Scientific Publication, 1976]. Moscow, 1977, pp. 119-133.

24. Protopopov, V.V. Russkaya mysl' o muzyke v XVII v. [Russian thought about music in the $17^{\text {th }}$ century]. Moscow, 1989.

25. Razumobsky, D. V. O notnykh bezlineynykh rukopisyakh tserkovnogo znamennogo peniya [About note nonlinear manuscripts of the church znamenny chant]. Moscow, 1863.

26. Razumovsky, D. V. Bogosluzhebnoye peniye pravoslavnoy greko-rossiyskoy tserkvi [Greek-Orthodox church chant]. Moscow, 1886.

27. RGADA. F. 381. Inv. 1. № 283.

28. RGADA. F. 381. Inv. 1. № 284.

29. RGADA. F. 381. Inv. 1. № 285.

30. RGADA. F. 381. Inv. 1. № 289.
31. RGADA. F. 381. Inv. 1. № 316 .

32. RGADA. F. 396. Inv. 2. № 316

33. RGADA. F. 1182. Inv. 1. № 45.

34. RGADA. F. 1182. Inv. 1. № 48.

35. RGADA. F. 1182. Inv. 1. № 51.

36. RGADA. F. 1182. Inv. 1. № 55 .

37. RGADA. F. 1182. Inv. 1. № 60

38. RGADA. F. 1182. Inv. 1. № 62.

39. RGADA. F. 1182. Inv. 1. № 63.

40. RGADA. F. 1182. Inv. 1. № 64.

41. RGADA. F. 1182. Inv. 1. № 66

42. RGADA. F. 1182. Inv. 1. № 67.

43. RGADA. F. 1182. Inv. 1. № 68.

44. RGADA. F. 1182. Inv. 1. № 69.

45. RGADA. F. 1182. Inv. 1. № 101

46. RGB. F. 37. № 361.

47. RGB. F. 210. № 1.

48. RGB. F. 299. № 212.

49. RGB. F. 299. № 284.

50. RGB. F. 310. № 176.

51. RGB. F. 310. № 1139 .

52. RGB. F. 379. № 1.

53. RGB. F. 379. № 16.

54. RGB. F. 379. № 18.

55. RGB. F. 379. № 29 .

56. RNB. Kir.-Bel. № 600/857

57. RNB. Kir.-Bel. № 601/858.

58. RNB. Kir.-Bel. № 605/862.

59. RNB. Kir.-Bel. № 612/869.

60. RNB. Kir.-Bel. № 617/874.

61. RNB. Kir.-Bel. № 627/884.

62. RNB. Kir.-Bel. № 628/885.

63. RNB. Kir.-Bel. № 630/887

64. RNB. Kir.-Bel. № 707/964

65. RNB. Sol. № 276/279,

66. RNB. Sol. № 277/280

67. RNB. Sol. № 277/282

68. RNB. Sol. № 277/286;

69. RNB. Sol. № 277/288;

70. RNB. Sol. № 277/292

71. RNB. Sof. № 492.

72. RNB. Q.XII.1.

73. Sakharov, I. P. Issledovaniya o russkom tserkovnom pesnopenii [Researching Russian church chant]. Moscow, 1849 , v. $1-2$.

74. Shusherin, Ioann. Izvestie o rozhdenii i vospitanii svyateishego Nikona patriarkha Moskovskogo i vseya Rossii [Account on the birth, uprising and life of His Holiness Nikon, the Patriarch of Moscow and All Russia]. Moscow, 1890.

75. Smolensky, S. V. Obschiy ocherk istoricheskogo i muzikalnogo znacheniya pevcheskikh rukopisey Solovetzkoy biblioteki. [The General essay of historical and musical value of Solovetsiy monastery' library chanting manuscripts]. Kazan', 1887.

76. Vladyshevskaya, T. F. K voprosu ob izucheniyi traditsiy drevnerusskogo pevcheskogo iskusstva [Studies of the Old Russian chant traditions']. Iz istorii russkoy $i$ sovetskoy muziki [From the history of the Russian and Soviet music]. Moscow, 1976, issue 2. pp.40-61.

77. Undolsky, V. M. Zamechanuya dlya istoriyy tserkovnogo peniya $\mathrm{v}$ Rossii [Notes for the history of the church chant in Russia]. Moscow, 1846.

78. Uspensky, N. D. Mezenets (v miru Stremoukhov) Alexandr [Alexander Mezenets (secular name Stremoukhov)]. Muzikal'naya entsiklopediya [Musical encyclopedia]. Moscow, 1976, v. 3, p. 493.

Received June 05, 2017 


\section{ПОДГОТОВКА И ПРОВЕДЕНИЕ МУЗЫКАЛЬНОЙ РЕФОРМЫ В РОССИИ 1650-1660-х гг.}

\section{Н. П. Парфентьев}

В статье рассматривается практическая деятельность властей по организации специальных комиссий, состоящих из ведущих мастеров церковно-певческого искусства, для устранения в нем негативных явлений и проведения реформы. На основе документальных и повествовательных источников уточняются даты работы и состав комиссий, общие результаты их деятельности.

Ключевые слова: древнерусское иерковно-певческое искусство, раздельноречие, исправление певческих книг, комиссии дидаскалов.

\section{Литература и источники}

1. Акты, собранные в библиотеках и архивах Российской империи Археографической экспедицией. СПб., 1836. Т.4.

2. Александр Мезенец и прочие. Извещение... желающим учиться пению (1670 г.) / публ., перев., историч. исслед. Н. П. Парфентьева ; коммент. и исслед. памятника 3. М. Гусейновой. - Челябинск, 1996.

3. Азбука знаменного пения (Извещение о согласнейших пометах) старца Александра Мезенца (1668-го года) / Изд. С. В. Смоленский. - Казань, 1888.

4. Бессонов, П. А. Судьба нотных певческих книг / П. А. Бессонов // Православное обозрение. - М., 1864. № 5. - C. 28-30.

5. БРАН. Арханг. № 30.

6. БРАН. Арханг. № 35.

7. БРАН. Арханг. № 40.

8. БРАН. Арханг. № 41.

9. БРАН. Арханг. № 43.

10. БРАН. Арханг. № 44.

11. Бражников, М. В. Древнерусская теория музыки /

М. В. Бражников. - Л., 1972.

12. ГИМ. Синод. певч. № 219.

13. ГИМ. Синод. певч. № 727.

14. ГИМ. Синод. певч. № 728.

15. Дополнения к Актам историческим, собранные и изданные Археографической комиссией. Т. 3. - СПб., 1848.

16. Евгений. О русской церковной музыке // Отечественные записки. - СПб., 1821. - С. 156.

17. Игнатьев, А. А. Церковно-правительственные комиссии по исправлению богослужебного пения русской церкви во второй половине XVII в. / А. А. Игнатьев. Казань, 1910. - С. 32-35.

18. Мансветов, И. Как у нас правились церковные книги / И. Мансветов. - М., 1883.

19. Металлов, В. М. Азбука крюкового пения / В. М. Металлов. - М., 1899.

20. Металлов, В. М. К вопросу о комиссиях по исправлению богослужебных певческих книг русской церкви в XVII в. / В. М. Металлов // Богословский вестник. Сергиев-Посад, 1912. - Т. 2. № 6. - С. 423-450.

21. Миронова, Н. В. О методике обучения древнерусскому певческому искусству / Н. В. Миронова, Н. П. Парфентьев // Из истории духовной культуры дореволюционного Урала. - Свердловск, 1979. - С. 85-89.
22. Преображенский, А. В. Культовая музыка в России / А. В. Преображенский. - Л., 1924.

23. Протопопов, В. В. Нотная библиотека царя Федора Алексеевича / В. В. Протопопов // Памятники культуры. Новые открытия. Ежегодник за 1976 г. - М., 1977. C. $119-133$.

24. Протопопов, В. В. Русская мысль о музыке в XVII в. / В. В. Протопопов. - М., 1989.

25. Разумовский, Д. В. О нотных безлинейных рукописях церковного знаменного пения / Д. В. Разумовский. - М., 1863.

26. Разумовский, Д. В. Богослужебное пение православной греко-российской церкви / Д. В. Разумовский. М., 1886.

27. РГАДА. Ф. 381. Оп. 1. № 283.

28. РГАДА. Ф. 381. Оп. 1. № 284.

29. РГАДА. Ф. 381. Оп. 1. № 285.

30. РГАДА. Ф. 381. Оп. 1. № 289.

31. РГАДА. Ф. 381. Оп. 1. № 316.

32. РГАДА. Ф. 396. Оп. 2. № 316.

33. РГАДА. Ф. 1182. Оп. 1. № 45.

34. РГАДА. Ф. 1182. Оп. 1. № 48.

35. РГАДА. Ф. 1182. Оп. 1. № 51.

36. РГАДА. Ф. 1182. Оп. 1. № 55.

37. РГАДА. Ф. 1182. Оп. 1. № 60.

38. РГАДА. Ф. 1182. Оп. 1. № 62.

39. РГАДА. Ф. 1182. Оп. 1. № 63.

40. РГАДА. Ф. 1182. Оп. 1. № 64.

41. РГАДА. Ф. 1182. ОП. 1. № 66.

42. РГАДА. Ф. 1182. Оп. 1. № 67.

43. РГАДА. Ф. 1182. Оп. 1. № 68.

44. РГАДА. Ф. 1182. Оп. 1. № 69.

45. РГАДА. Ф. 1182. ОП. 1. № 101.

46. РГБ. Ф. 37. № 361.

47. РГБ. Ф. 210. № 1.

48. РГБ. Ф. 299. № 212.

49. РГБ. Ф. 299. № 284.

50. РГБ. Ф. 310. № 176.

51. РГБ. Ф. 310. № 1139.

52. РГБ. Ф. 379. № 1.

53. РГБ. Ф. 379. № 16 .

54. РГБ. Ф. 379. № 18.

55. РГБ. Ф. 379. № 29.

56. РНБ. Кир.-Бел. № 600/857

57. РНБ. Кир.-Бел. № 601/858.

58. РНБ. Кир.-Бел. № 605/862. 
59. РНБ. Кир.-Бел. № 612/869.

60. РНБ. Кир.-Бел. № 617/874

61. РНБ. Кир.-Бел. № 627/884.

62. РНБ. Кир.-Бел. № 628/885.

63. РНБ. Кир.-Бел. № 630/887

64. РНБ. Кир.-Бел. № 707/964

65. РНБ. Сол. № 276/279,

66. РНБ. Сол. № 277/280

67. РНБ. Сол. № 277/282

68. РНБ. Сол. № 277/286;

69. РНБ. Сол. № 277/288;

70. РНБ. Сол. № 277/292

71. РНБ. Соф. № 492.

72. РНБ. Q.XII.1.

73. Сахаров, И. П. Исследования о русском церковном песнопении / И. П. Сахаров. - Ч. 1-2. - М., 1849.
74. Шушерин, И. Известие о рождении и воспитании и о житии святейшаго Никона, патриарха Московского и всея России / И. Шушерин. - М., 1890.

75. Смоленский, С. В. Общий очерк исторического и музыкального значения певческих рукописей Соловецкой библиотеки и «Азбуки певчей» Александра Мезенца / С. В. Смоленский. - Казань, 1887.

76. Владышевская, Т. Ф. К вопросу об изучении традиций древнерусского певческого искусства / Т. Ф. Владышевская // Из истории русской и советской музыки. - Вып. 2. - М., 1976. -С. 40-61.

77. Ундольский, В. М. Замечания для истории церковного пения в России / В. М. Ундольский. - М., 1846.

78. Успенский, Н. Д. Александр Мезенец / Н. Д. Успенский // Музыкальная энциклопедия. - Т. 3. М., 1976. - Стб. 493.

ПАРФЕНТЬЕВ Николай Павлович, заведующий кафедрой теологии, культуры и искусства, ЮжноУральский государственный университет (Челябинск, Россия), доктор исторических наук, доктор искусствоведения, профессор, заслуженный деятель науки Российской Федерации. Автор более 100 научных трудов, в том числе 6 монографий, в области истории духовной культуры России и древнерусского искусства. E-mail: parfentevnp@susu.ru

Поступила в редакцию 05 июня 20172. 